\title{
SOME FACTS ABOUT OIL AND GAS INDUSTRY
}

\author{
Dragan S. Marković, \\ Dragan Cvetković, \\ Dejan Živković
}

Singidunum University

32 Danijelova Street, Belgrade, Serbia

\section{Correspondence:}

Dragan S. Marković

e-mail:

dsamarkovic@singidunum.ac.rs

\begin{abstract}
:
The population has doubled in the last half century and there are currently over seven billion people on the planet. During this period, a constant growth of Gross Domestic Product was recorded on the global level. As known, the population and income are the key factors which affect the growth of energy demand. Although the use of alternative sources of energy is growing annually, the increase is relatively modest and during next two or three decades they will be more supplement than the substitute for fossil fuel. Growing energy demand on the world level in the next two decades will be a great challenge which is to be successfully met only by revolutionary scientific-technological discoveries applicable in the oil and gas industry. This paper elaborates on the current circumstances and challenges that oil and gas industry face with. Nanotechnology with its fascinating, newly discovered nanomaterials offers some solutions for this sector and makes it more efficient and successful and thus makes the energy supplies in the future more certain.
\end{abstract}

Key words:

oil, gas, sustainability, efficiency, nanotechnology.

\section{INTRODUCTION}

According to the assessment of the demographers [1], the largest growth of the population will be recorded in the developing countries while the countries which are already developed will remain relatively stable. High rates of growth are expected in India, which will probably be the most populated country in the world by 2020, as well as African countries, because of the estimated improvement of the social-economic conditions and upgrading health services. With the growth of population, developing countries will be characterized by migrations from the rural areas to the cities, i.e. urbanization.

As McKinsey Global Institute [2] assesses, by 2025440 cities from the developing countries will bring the half of the global GDP growth. Urbanization and increase of consumers in the developing countries will create real estate demand, infrastructure, automobiles, comfort and energy resources.

According to the statistic reports of relevant world institutions [3], the world economy is growing. Global BDP has been growing on average by $3.5 \%$ since 1970 and this trend shall continue by 2035 . 
As the consequence of population and economy growth, the energy consumption grows. In the last two decades, the demand for energy has grown up to $50 \%$, and is expected to keep growing up to $40 \%$ in the next two decades. Strictly mathematically speaking, this slowdown will not matter much because the growth of $40 \%$ up to 2035 roughly speaking means adding combined present energy consumption of USA and China.

Meeting this demands entails at least three questions. First is sufficiency, i.e. is there enough energy to satisfy the demand? The second is safety, i.e. can different countries have access to the energy they need? The third is sustainability, i.e. can the demand for energy be satisfied without the unacceptable influence on the eco system of the planet?

Regarding sufficiency, if we take into consideration the fact that civilization today relies on fossil fuel up to the amount of $80 \%$, it can be said that energy is sufficient. Expert analysis [4] shows that the world has abundance of technically renewable resources to satisfy energy demand up to 2050 . There is about 45 trillion barrels of the discovered reserves of the oil and gas equivalents. This amount has nearly doubled by the unconventional sources including shale and gas. These are mainly onshore sources and only 1.7 barrels have been produced up till now.

If we talk about safety great energy consumers should be considered, nations or group of states (like EU), because not all of them are great producers of energy as well. So, they relay on supplying from other countries. Thus, energy safety is one of the dominant geopolitical questions and the world is undeniably in the phase of significant geopolitical turbulence at the moment.

Despite the above mentioned, the price of oil is dropping. That is, by all means, the result of complex geopolitical situation and regarding supply and demand. The market shows resilience and keeps supplying the world with energy despite considerable disturbances like wars, sanctions and weather disasters. All mentioned implies that the world instead of being divided into the countries which are energy-dependant and those that are energyindependent becomes in reality energy-interdependent. This fact leads us to the problem of sustainability.

Sustainability is defined as "the development which satisfies the needs of present generation without endangering the possibility of satisfying the needs of future generations." [5]

Because of the growing influence of eco- movements and general concern over the evident climate change, the goal of the companies in this sector is redefined and is related to making value for the company shareholders, upgrading employees standard and quality of life as well as contribution to economy, ecology and social benefit of the users, suppliers and states where companies are placed.

Energy is necessary for all general operations in this area and its participation considerably effects final operating expenses. By using energy effectively, the companies reduce their costs and make their product more accessible to final users, enabling them to be more profitable. Because of this companies put considerable means into energy-efficient technologies.

Activity in this area is detected in promotion of renewable energy sources. French TOTAL is one of rare companies which increased investments into green energy and is actively included into photo-voltage energy area. Norwegian STATOIL has significant longterm plans and investments into wind-operated power plants.

Conoco Philips is an example of the company which tries to reduce its bad influence on biodiversity and beside biodiversity risk evaluation when estimating its investments, makes action plans and projects for areas of high-risk value.

The transition from use of energy produces with high percentage of carbon (coal and oil) to the ones with low percentage of carbon (gas) as well as encouraging innovations influencing lowering of carbon emission should be considered as sustainability.

However, the area is still divided into companies whose supervising committees are working on sustainability and those that show no evidence of engagement in this matter.

It is obvious that boosted exploitation of gas and oil has at the moment positive effect on economy recovery. However, no one is presenting information on extreme costs of water pollution near exploitation sites, climate change, endangering health of people etc.. The costs are still unknown.

If we compare the economic growth in this area, the growth of sustainability is more than modest. Although the financial means invested into lowering the greenhouse effect, saving the quality of water, employees safety, etc. reduce negative influences, it is still far from green industry.

The remaining part of the work is organized in four sections. In the second section, oil and gas sector circumstances are considered. In the third, the contribution of nanotechnology to the efficient management through new patent solutions is stated. In the fourth section, chronology of the events which explain up to a point what has happened and is still happening in this area are discussed. The last sections presents concluding remarks. 


\section{CURRENT CIRCUMSTANCES OF OIL AND GAS INDUSTRY}

Oil is the most important commodity in the world trade exchange participating $15 \%$ and the most common load in marine transportation. High quality energy product and irreplaceable raw material in chemical industry. Possession of oil means power. Oil has often been the means of geopolitical conflict through history. Its history is the one full of price ups and downs. Recent events should be regarded accordingly. Since 1990 this has been the deepest fall. Figure 1 shows the average price flow from 2000 till today.

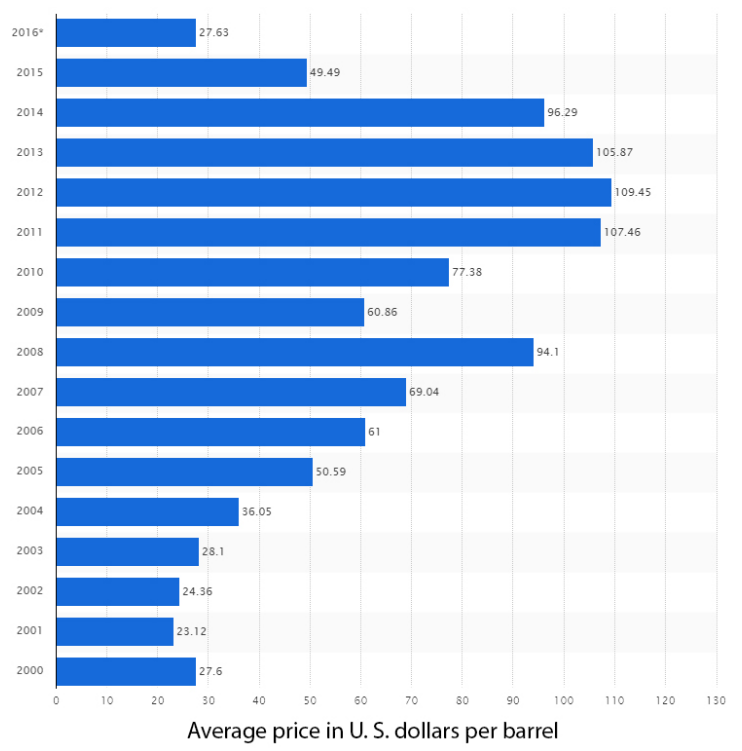

Figure 1. Average oil price on world market Source: Statista, http//www.statista.com

Speculation on the reasons of raw oil price downfall during 2015 and continuing in 2016 as also vary from geopolitical conspiracy theories to simple explanations suggesting that long-term high oil price stimulated enormous investment influx in new technologies like freaking or drilling in deep water. These technologies, combined with real decrease of global oil supply led to extreme raw oil price downfall. The world expected OPEC to limit production, but that did not happen. Some analysts interpreted this as a calculated move aiming to bring energy (even political) blow to the USA competition (freaking) and Europe (renewable energy sources). On the other hand, it can be considered wider on relation USA-Russia-Saudi Arabia or USA-OPEC, etc. Is it really so, the time will show [6].
Acknowledging foreseen population growth trends, urbanization, economy and energy demand, companies for exploration and exploiting will have to find new sources of this energy product. New technologies will extend "life" of the existing drill holes through their enhanced recovery. This improvement will help, but it will not be enough.

New considerable oil findings must be made and the process is getting harder daily. The explorers will have to search over 3500 meters under the ground and make drill holes which will give less oil with higher recovery price then today. Some new sources will be from the onshore drill holes in the countries which are geographically, culturally and politically distant from the consumers' nations and thus will effect the transportation price.

The majority of new findings will be in deep waters off African, Brazilian, Canadian and Norwegian coast on depths over 2500 meters. The Arctic region will increase in importance as well as East and West coast of USA. The discovery and production process of such finds is extremely expensive because of the harmful materials and demanding eco standards, oil processing and refinement of this quality is long-lasting and requires highly sophisticated equipment which increases the costs. Operating costs in such expensive process directly influence the raw oil price and that shows the future raw oil price flow.

Water is the key component for research and production of upstream sector regardless of the technology used. For recovery of one barrel of oil, one to four barrels of water are polluted depending on the technology used.

For instance, revolutionary method of hydraulic fracturing pumps water and chemicals into shale sediments to extract gas. Procedure consists of placing drilling machinery, drilling vertical drill hole on depth from 20004000 meters and then drilling horizontally. Then, 5-30 million liters of freaking fluid (it consists of water, sand and chemicals) is pumped in under great pressure. This fluid penetrates into cracks of rocks, destroys them and suppresses gas trough the drill. However, it frees methane (the greenhouse effect gas), benzene and other carcinogenic substances which pollute the air as well as ground and underground water. It influences the erosion too.

Confrontation of short term profit and long term sustainability is most clearly expressed in oil and gas industry. Not only the competition, oil price downfall and huge increase of energy demand but fear of climate change and strong common effort to decrease emission of $\mathrm{CO} 2$ and minimize fossil fuel consumption are important factors which define business strategies of oil and gas companies. Facing numerous challenges companies relied on science and technology. 


\section{CONTRIBUTION OF NANOTECHNOLOGY TO OIL AND GAS INDUSTRY EFFICIENCY}

It is common knowledge that technology has an important role in research, production, processing and transportation of raw oil. That is why the companies from that field have invested a lot in research and development of technologies which will enable them to enhance their business limits.

Nanotechnology has recently drawn public attention and become an interesting field of research. Companies worldwide have quickly reacted to the rise of nanotechnology by engaging considerable resources in order to provide convenience of this technology. Oil and gas companies are serious in their intention to take part in this international competition to ensure benefits from this technology use. The most obvious characteristic of nanotechnology is development of materials with better performances in wider sense. All materials have physicchemical performances depending on the critical size of particles. Thus, geometric structure, chemical bonds, the ionization potential, electrical properties, optical properties, mechanical strength, melting point, magnetic properties, etc. are influenced by the particle size [7].

When material dimensions are reduced from macro to nano size, important changes are noticed in electric conductivity, optical absorption, chemical reactivity and mechanical features. Materials with range from $100 \mathrm{~nm}$ to atomic level can have various or improved characteristics compared to the materials bigger in size.

Two main reasons for the change are relative surface and domination of quantum effects. The increase of the surface will result in adequate increase of corresponding chemical reactivity and creation of certain nano particles used as catalysts. As the site of materials is reduced on tenths of nanometers or less, quantum effects start acting, which can considerably change optic, magnetic or electrical performances of material.

Nanotechnology offers wide spectra of possibilities and adds new performances to tee wide range of materials used in oil and gas sector. The current aims of using nanomaterials are efficiency improvement in finds research, enlarging the recovery of oil finds, boosting the equipment reliability, enabling analysis of emulsion characteristics in real time, improvement of energy efficiency in production, reducing corrosion effects, remediation of formation damage, reducing the impact on the environment, etc.

Patents are one of the most important innovation indicators in evaluation of technological competitive- ness because they are one of the outcoming results in the development and research process. They can also be seen as potential factors of the future economic activity.

Statnano [8] conducted a study regarding the approved and registered oil and gas company patents related to nanotechnology. The research included 10 great companies from this sector, ExxonMobil, Chevron, Schlumberger, Baker Hughes, Halliburton, Royal Duch Shell, BP, Eni and Conoco Phillips (see Table 1). They have established 836 patents in this sector.

\begin{tabular}{lc}
\hline \multicolumn{1}{c}{ Company } & No. Of Patents \\
\hline Chevron & 44 \\
\hline Schlumberger & 91 \\
\hline Eni & 18 \\
\hline ExxonMobil & 142 \\
\hline Baker Hughes & 217 \\
\hline Halliburton & 96 \\
\hline Royal Dutch Shell & 99 \\
\hline BP & 42 \\
\hline Total & 63 \\
\hline ConocoPhilips & 24 \\
\hline Table 1. Nanotechnology related Patents \\
in the oil and gas industry \\
Source: Statnano \\
\end{tabular}

It is immediately noticed that Baker Hughes company is represented with 26\%, ExxonMobil 17\% and Royal Duch Shell with average 12\%. The overview of patent chronology in the mentioned study shows that from 1970-1996, less than 10 patents have been submitted. From that year on it grows reaching its peak in 2011 with 107 patents. Another characteristic of the year 2011 is the beginning of the „Arab spring“.

Despite the fact that economic crisis lasts for few years, great oil companies have expected a lot from research, development and application of nanotechnology. It can be stated that despite yearly decrease in the number of patents from 2011, nanotechnology is still the leading theme in this sector.

The importance that oil companies give to scientific research can be seen from the following data. ExxonMobil hired $1900 \mathrm{PhDs}$ in year 2002 [9], Russian Rossneft employed over $650 \mathrm{PhDs}$ in 2013 [10]. Arabic company Saudi Aramco had in its development sector $674 \mathrm{em}-$ ployees and 173 of them were PhDs ie.,26\%. There were 1157 people in the development sector there years later, of which 434 are $\mathrm{PhDs}$, i.e. $30 \%$ [11]. This company had 
58 patents accepted by the, United States Patent and Trademark Office in 2012, in 2013 year 53 patents and in 2014 record 99 patents yearly [12]. Aramco has 24 patents related to nanotechnology.

Russia founded Rosnano in 2007 in order to boost research activity in this field [13]. Research is mainly focused on domestic economy and a small number of patents is registered abroad. It is estimated regarding the number of registered patents that this field is still not a priority [14]. It should be mentioned that there is a specialization agreement between the countries of BRICS (Brazil, Russia, India, China and South Africa) where India holds the leading role in the nanotechnology research [13].

\section{DENOUEMENT TIME}

The decision on shale mass production was influenced by the raw oil price as well as the power gained from this production. The US Ministry of Energy estimated in 2004 that shale can be competitive if the price of oil rises above $54 \$$ per barrel for „above ground“ technology or $35 \$$ per barrel for ,in situ“ technology. Shale boom has started in 2007 with enhanced recovery program in the Appalachian (Devonian) Basin find. Output growth was enormous and is still rising. Although according to the report of the World Bank downfall of the production is expected [15]. New technology has enabled activation of technologically unavailable and economically unprofitable resources as well as relatively cheap energy product help lapsing American economy.

According to data from Energy Information Administration, the United States have even production of oil and gas. The US is the world leader in shale gas production. US have been relying on their cheap gas and are no longer great oil importers. This decision of the US resulted in the fact that Saudi Arabia lost part of that market.

Saudi Arabia, on the other hand, produces petroleum. For years now Saudi Arabia and Russia are altering on the first place of oil production. Russia is the greatest manufacturer and exporter of the natural gas. With introduction of sanctions Russia is constrained to search other markets, primarily in Asia (China and India). In these circumstances, Saudi Arabia tends to take over the European market. It is theoretized that Saudi Arabia is reducing prices of oil in order to push out America, which cannot export oil and gas from shale because their companies will operate with heavy losses.

Gas is much cheaper on the American than the European market because of the frocking technology. America completely satisfies its needs and with restrictive measures tries to keep cheap energy products on the market and thus support its economy recovery. At the current prices, the small number of shale drill holes in the US is economically viable. Some analysts say that their viable price is around $80 \$$ per barrel. The costs of making export LNG terminal for intake, i.e. import for regasification, then transportation by LNG tankers to large distances as well as trading margins influence the fact that gas from shale would not be concurrent with the price on European market in comparison to Russian gas.

Simultaneously, great manufacturer and oil exporter Saudi Arabia, does not tend to reduce production, and the global economy keeps slowing down, so the management of oil companies and the investors expect market to stay in the upheaval till 2017.

According to writing of the New York Times, oil companies whose income had large boost in previous years are suffering income downfall now. Accordingly, they have stopped exploitation on the two thirds of their drill holes and considerably reduced investment into research and production. Numerous companies went bankrupt and it is estimated that approximately 250000 people from this sector lost their jobs.

The members of the OPEC and other significant manufacturers of oil and gas are prepared to "freeze" their production. The press quoted the words of Russian Minister of energy Alexandar Novak stating that the countries which produce $73 \%$ of oil in the world are ready to do so.

It is difficult to predict whether these are the signs of ending America's double confrontation with Russia and Saudi Arabia.

\section{CONCLUSION}

The question is: who gains and who losses in this geopolitical game? Downfall of oil prices on the world market has various consequences for different players. Small consumers in many countries spend less money on fuel, because retail prices are significantly reduced, while consequences for industry and economies dependant on oil production will be very negative. Those who gained on the industrial side will probably be refineries in Europe which the could make profit because of law raw oil price.

The greatest net losers are states - big producers and exporters of oil, especially those with large external debit and deficit. Low oil price has conditioned some projects not to be profitable. Many companies suffered fall of liquidity and reduction of income, which made insufficient funds for investment planning and led to releasing of employees. 
Undoubtfully, nanotechnology has already enabled and will keep enabling this sector to claim unreachable resources in the past and thus postpone the end of fossil fuel. Mankind is given a chance to use cleverly the time bought and find a new ecologically acceptable long-lasting energy solution, thus securing safe energy future for itself.

\section{LITERATURE}

[1] Patricia Clarke Annez and Robert M. Buckley, Urbanization and Growth: Chapter 1 Setting the Context, World Bank Publications, November 2008, http://siteresources.worldbank.org/EXTPREMNET/Resources/489960-1338997241035/ Growth_Commission_Vol1_Urbanization_ Growth.pdf, last accessed: 19. march 2016.

[2] Richard Dobbs, Jaana Remes, James Manyika, Charles Roxburgh, Sven Smit and Fabian Schaer, Urban world: Cities and the rise of the consuming class, McKinsey Global Institute, June 2012, http:// www.mckinsey.com/global-themes/urbanization/ urban-world-cities-and-the-rise-of-the-consuming-class, last accessed: 19. march 2016.

[3] World Bank Group. 2015. Global Economic Prospects, January 2015: Having Fiscal Space and Using It. Washington, DC: World Bank. doi: 10.1596/978-1-4648-0444-1. License: Creative Commons Attribution CC BY 3.0 IGO, https:// www.worldbank.org/content/dam/Worldbank/ GEP/GEP2015a/pdfs/GEP15a_web_full.pdf, last accessed: 19. march 2016.

[4] BP Technology Outlook, November 2015, http:// www.bp.com/content/dam/bp-country/nl_nl/documents/bp-technology-outlook.pdf, last accessed: 19. march 2016.

[5] Report of the World Commission on Environment and Development: Our Common Future, March 1987., http://www.un-documents.net/our-common-future.pdf, last accessed: 19. march 2016.

[6] 2016 Oil and Gas Trends, PwC's Strategy\&, http:// www.strategyand.pwc.com/perspectives/2016-oiland-gas-trends, last accessed: 19. march 2016.

[7] Nanotechnology, Encyclopedia Britannica, http:// www.britannica.com/technology/nanotechnology, last accessed: 19. march 2016.
[8] Statnano, Applications of Nanotechnology in Petroleum Industry Based on Active Enterprises, January 2016., http://www.statnano.com/news/52936, last accessed: 19. march 2016.

[9] ExxonMobil, ExxonMobil Careers: Fuel For Thought, http://www.indiana.edu/ jobtalk/ppt/ SCOOPs/2002-2003/02-04/ExxonMobil.ppt, last accessed: 19. march 2016.

[10] Igor Seachin, Rosneft President Igor Sechin keynote address at CERA Week, Houston, Texas, March 6, 2013., http://www.rosneft.com/attach/0/02/99/cera_speech_en.pdf

[11] Amar Arunawi, Saudi Aramco, Transforming Saudi Aramco technology, Japan Cooperation Center Petroleum JCCP Conference, https://www. jccp.or.jp/international/conference/docs/S2-1Mr. Ammar\%20A.\%20AlNahwi\%20Presentation\%20 Ver.\%2011.pdf, January 2016, last accessed: 19. march 2016.

[12] Saudi Aramco, Generating Breakthroughs Across Tha Value Chain, http://www.saudiaramco.com/ content/dam/Publications/annual-review/2014/ AR-2014-SaudiAramco-English-generatingbreakthroughs.pdf, 2014., last accessed: 19. march 2016.

[13] Anatoly Chubais, A Breakthrough Industry, BRCS Business Magazine, http://www.bricsmagazine. $\mathrm{com} /$ en/articles/a-breakthrough-industry, last accessed: 19. march 2016.

[14] Alexey Streletskiy, Vladimir Zabavnikov, Emil Aslanov, Dmitriy Kotlov, Patent Landscape for Nanotechnology, FORESIGHT AND STI GOVERNANCE, Vol. 9, No 3, 2015., https://foresightjournal.hse.ru/data/2015/10/01/1074300406/3Strelezki-40-53.pdf, last accessed: 19. march 2016.

[15] Commodity Markets Outlook, A World Bank Quarterly Report, January 2016,

http://pubdocs.worldbank.org/pubdocs/publicdoc/2016/1/991211453766993714/CMO-Jan2016-Full-Report.pdf, last accessed: 19. march 2016.

[16] Clifford Crauss, Oil Prices: What's Behind the Drop? Simple Economics, The New York Times, March 2016., http://www.nytimes.com/interactive/2016/business/energy-environment/oil-prices.html?_r=0, last accessed: 19. march 2016. 